\title{
DRUGI I TRZECI LIST ŚW. JANA W KOMENTARZACH OJCÓW KOŚCIOŁA
}

Drugi i Trzeci List św. Jana to księgi Nowego Testamentu, którym poświęca się niewiele uwagi, może nawet należą one do najrzadziej czytanych oraz komentowanych listów. Decyduje o tym fakt, że są to pisma bardzo krótkie, ponadto zawierają niewiele istotnych treści teologicznych. Niewielkie zainteresowanie nimi widoczne jest również w pismach ojców Kościoła, gdyż zaledwie kilku z nich poświęca im osobne komentarze, kilku innych nawiązuje do nich w swych pismach poruszających inne treści i tematy.

Również i dziś egzegeci rzadko podejmują badanie Drugiego i Trzeciego Listu św. Jana. Listy te są komentowane w ramach trzech listów Janowych, tam zaś lwią część komentarza poświęca się Pierwszemu Listowi, a do pozostałych dwóch czyni się jedynie pojedyncze nawiązania. Tak jest na przykład w komentarzach F. Gryglewicza, I.H. Marshalla, C.G. Krusego oraz S.S. Smalleya czy też w opracowaniach S. Gądeckiego, S. Mędali, A.R. Sikory, J. Czerskiego i W. Jończyka ${ }^{1}$. W ostatnich latach ukazały się bardzo nieliczne opracowania analizujące treść Drugiego lub Trzeciego Listu Janowego, wśród których można wymienić prace H.L. Landrus, B.L. Campbella, I. Lorencina, M.D. Jensena czy T. Griffitha ${ }^{2}$.

1 F. Gryglewicz, Listy katolickie. Wstęp, przekład z oryginatu, komentarz, Pismo Święte Nowego Testamentu 11, Poznań 1959; I.H. Marshall, The Epistles of John, The New International Commentary on the New Testament, Grand Rapids 1978; C.G. Kruse, The Letters of John, Pillar New Testament Commentary, Grand Rapids 2000; S.S. Smalley, 1, 2 and 3 John, World Biblical Commentary, Grand Rapids 2008; S. Gądecki, Wstęp do pism Janowych, Gniezno 1991; S. Mędala, Trwanie w prawdzie (Drugi List św. Jana), w: Ewangelia św. Jana. Listy powszechne. Apokalipsa, red. J. Frankowski, oprac. R. Bartnicki i in., Wprowadzenie w myśl i wezwanie ksiąg biblijnych 10, Warszawa 1992, s. 90-96; S. Mędala, Gościnność chrześcijańska (Trzeci List św. Jana), w: Ewangelia św. Jana ..., dz. cyt., s. 97-101; A.R. Sikora, ,, Widzenie” Boga w Listach św. Jana, ,Verbum Vitae” 16 (2009), s. 183-198; J. Czerski, Ewangelia i Listy św. Jana. Wprowadzenie literackie, historyczne i teologiczne, Opolska Biblioteka Teologiczna 156, Opole 2016; W. Jończyk, Relacyjne aspekty teologii Ewangelii i Listów św. Jana, „Studia Bobolanum” 1 (2017), s. 177-193.

2 H.L. Landrus, Hearing 3 John 2 in the Voices of History, „Journal of Pentecostal Theology” 11 (2002), no. 1, s. 70-88; B.L. Campbell, Honor, Hospitality and Haughtiness: The Contention for Leadership in 3 John, „Evangelical Quarterly” 77 (2005), no. 4, s. 321-341; I. Lorencin, Hospitality versus Patronage: An Investigation of Social Dynamics in the Third Epistle of John, „Andrews University Seminary Studies” 46 (2008), no. 2, s. 165-174; M.D. Jensen, Jesus ,Coming” in the Flesh: 2 John 7 and Verbal Aspect, „Novum Testamentum” 56 (2014), 
Drugi i Trzeci List św. Jana to pisma krótkie, ograniczone do takiego rozmiaru, jaki można było pomieścić na jednej karcie papirusu. Listy te najprawdopodobniej zostały napisane i wysłane razem, z tym że $2 \mathrm{~J}$ jest adresowany do wspólnoty chrześcijan, natomiast $3 \mathrm{~J}-$ do jednej konkretnej osoby $\mathrm{z}$ tej wspólnoty, tj. do Gajusa. Listy zostały prawdopodobnie wysłane z Efezu do miasta, w którym Kościołowi domowemu przewodniczył Gajus. Według Konstytucji apostolskich $(7,46)$, które podają wykaz biskupów wysłanych przez apostołów do różnych miast, imię Gajus nosił pierwszy biskup Kościoła w Pergamonie. Istnieje możliwość, że jest to ta sama osoba, do której został skierowany $3 \mathrm{~J}$. Autor listów nie przedstawia się imieniem, lecz pisze o sobie „,prezbiter” (starszy), jednak ponieważ oba listy ( $2 \mathrm{~J}$ i $3 \mathrm{~J}$ ) zdradzają jednoznacznie charakter Janowy, rozpoznaje się rzeczonego „prezbitera” jako św. Jana Ewangelistę․ Tematy, które można znaleźć w Drugim i Trzecim Liście św. Jana, bardziej wymienione niż poruszone, to wcielenie Syna Bożego, miłość braterska, zachowywanie przykazań Boga i przestroga przed błędnowiercami $(2 \mathrm{~J})$ oraz prawda, widzenie Boga i gościnność chrześcijańska (3 J).

Celem niniejszej pracy jest prezentacja treści komentarzy do Drugiego i Trzeciego Listu św. Jana Apostoła napisanych przez ojców Kościoła, do których tradycyjnie zalicza się teologów żyjących w okresie od I do VIII w. Analiza zostanie przeprowadzona na podstawie tekstu dostępnego w wydaniu Jacques'a-Paula Migne'a: Patrologiae Cursus Completus. Series Latina, Parisiis 1844-1865 (PL) oraz Patrologiae Cursus Completus. Series Graeca, Parisiis 1856-1866 (PG). Tekst polski badanych tekstów greckich i łacińskich zostanie podany w tłumaczeniu własnym autora pracy, o ile nie zaznaczono inaczej ${ }^{4}$.

Zwięzłość i osobisty charakter nie sprzyjały rozpowszechnieniu $2 \mathrm{~J}$ i $3 \mathrm{~J}$. U ojców apostolskich można znaleźć jedynie ślady znajomości tych listów, mianowicie u św. Polikarpa, który przytaczając $1 \mathrm{~J}$ 4,2-3, ma prawdopodobnie na uwadze także 2 J 4, oraz u Ignacego Antiocheńskiego (List do Smyrneńczyków, 4, 1; por. $2 \mathrm{~J}$ 10). Kanon Muratoriego nie wylicza wprawdzie $2 \mathrm{~J}$ ani $3 \mathrm{~J}$, lecz wyraża się o listach Janowych w liczbie mnogiej. Św. Ireneusz dwukrotnie cytuje $2 \mathrm{~J}$ na równi z innymi pismami NT i przypisuje go Janowi, uczniowi Pana (Adversus haereses, I, 16, 3; III, 16, 8). Dionizy Aleksandryjski trzy listy Janowe przypisuje Janowi Apostołowi. Św. Hieronim autorstwo 2-3 J przypisuje Janowi Prezbiterowi (De viris illustribus, 18; PL 23, k. 623, 637). Korzysta z nich jednak jako z pism kanonicznych, w spisie zaś listów katolickich przypisuje je z kolei św. Janowi,

fasc. 3, s. 310-322; Т. Griffith, The Translation of O ПРОАГQN in 2 John 9, „,Tyndale Bulletin" 67 (2016), no. 1, s. 137-144.

3 F. Gryglewicz, Listy katolickie..., dz. cyt., s. 440-441; S. Gądecki, Wstęp do pism Janowych, dz. cyt., s. 102; S. Mędala, Trwanie w prawdzie..., art. cyt., s. 91; S. Mędala, Gościnność chrześcijańska..., art. cyt., s. 97.

4 Cytaty biblijne, za: Pismo Święte Starego i Nowego Testamentu w przekładzie z języków oryginalnych. Biblia Tysiaclecia, wyd. 5, Poznań 2000. 
który był Apostołem (Epistula 53, 9). Janowi Prezbiterowi przypisują te listy: św. Ambroży (Epistula 11, 4; PL 16, k. 946), Amfiloch z Ikonium i dekret papieża Gelazego 5 .

Tak więc w pierwszych dwóch wiekach chrześcijaństwa $2 \mathrm{~J}$ i $3 \mathrm{~J}$ co najwyżej krótko się wspomina, a pojedyncze odniesienia do tych dwóch ksiąg - podobnie jak to się dzieje w przypadku wszystkich listów katolickich - są jedynie znakiem ich obecności wśród ksiąg świętych. Można wywnioskować, że w początkach chrześcijaństwa, przede wszystkim Kościele wschodnim, istniała tendencja do traktowania wszystkich listów katolickich jako pewnej całości. Z biegiem czasu pojawiły się również osobne prace egzegetyczne poświęcone dwom małym listom Janowym ${ }^{6}$.

Wśród komentarzy ojców Kościoła omawiających Drugi i Trzeci List św. Jana można wymienić:

- Adumbrationes in Epistolam II Joannis (PG 9, k. 737-740) Klemensa Aleksandryjskiego, greckiego pisarza i teologa żyjącego na przełomie II i III w. († 215). Jest to część dzieła pod tytułem Hypotyposes - komentarza do Biblii w ośmiu księgach (Euzebiusz, Historia Ecclesiae, VI, 15), których tekst nie zachował się do naszych czasów. Dziś do dyspozycji pozostaje kilka dłuższych fragmentów tego dzieła (komentarze do $1 \mathrm{P}$, Jud, 1-2 J) zachowanych w łacińskim thumaczeniu sporządzonym w VI w. przez Kasjodora, noszące tytuł Adumbrationes in Epistulas catholicas ${ }^{7}$.

- In Epistolam divi Joannis secundam enarratio (PG 39, k. 1809-1810) oraz In tertiam divi Joannis Epistolam enarratio (PG 39, k. 1811-1812) - komentarze Dydyma Ślepego, żyjącego w Aleksandrii w IV w. († 398) ascety i nauczyciela. Jest to część dzieła In Epistolas catholicas brevis enarratio - krótkiego komentarza do wszystkich listów katolickich (choć Dydym miał obiekcje co do autentyczności 2 P), z polecenia Kasjodora przetłumaczonego w VI w. na łacinę przez Epifaniusza Scholastyka. Do czasów współczesnych dotrwało jedynie kilka fragmentów w języku greckim. Komentarz Dydyma stał się jednym z głównych źródeł dla późniejszych greckich katen, czyli komentarzy, które w formie „łańcucha” (gr. katena) zbierały i przedstawiały wypowiedzi różnych komentatorów dotyczących treści danej księgi biblijnej8.

5 F. Gryglewicz, Listy katolickie ..., dz. cyt., s. 440-442; S. Gądecki, Wstęp do pism Janowych, dz. cyt., s. 102; S. Mędala, Trwanie w prawdzie..., art. cyt., s. 91; S. Mędala, Gościnność chrześcijańska..., art. cyt., s. 97-98.

6 T. Skibiński, Listy katolickie w starożytności chrześcijańskiej, „Vox Patrum” 28 (2008), s. 945.

7 F. Drączkowski, Klemens Aleksandryjski, w: Encyklopedia katolicka, t. 9, red. A. Szostek, Lublin 2002, k. 99; T. Skibiński, Listy katolickie..., art. cyt., s. 946; por. R. Mees, Clemente di Alessandria, w: Dizionario patristico e di antichità cristiane, diretto da A. di Bernardino, vol. 1, Roma 1983, k. 709-710.

$8 \quad$ F. Drączkowski, Dydym Ślepy, w: Encyklopedia katolicka, t. 4, red. R. Łukaszyk, L. Bieńkowski, F. Gryglewicz, Lublin 1983, k. 414-415; T. Skibiński, Listy katolickie..., art. cyt., s. 946-47; por. P. Nautin, Didimo il Cieco, w: Dizionario patristico..., vol. 1, dz. cyt., k. 951. 
- In II Epistolam Joannis (PL 93, k. 119-122) oraz In III Epistolam Joannis (PL 93, k. 121-124) to komentarze Bedy Czcigodnego do Drugiego oraz Trzeciego Listu św. Jana. Beda, anglosaski mnich i doktor Kościoła żyjący na przełomie VII i VIII w. († 735), napisał wiele komentarzy do ksiąg biblijnych, wśród nich najobszerniejszy ze starożytnych komentarzy łacińskich do listów katolickich, zatytułowany Super Epistolas catholicas expositio, którego częścią są komentarze do 2 J i 3 J. Omawiając listy, Beda opierał się na ich tekście w tłumaczeniu Wulgaty, choć czasem sięgał też do wcześniejszych tłumaczeń Itala oraz do tekstu greckiego. Wykorzystywał również teksty Ambrożego, Hieronima, Augustyna i Grzegorza Wielkiego, jednak nie był prostym kompilatorem dzieł poprzedników, lecz dodawał również komentarze własne?.

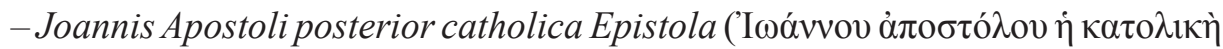

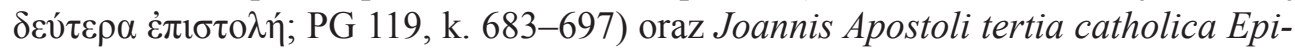

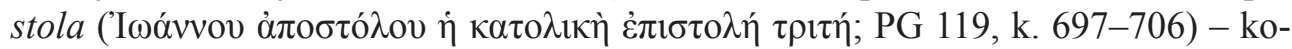
mentarze do Drugiego oraz do Trzeciego Listu Jana przypisywane Ekumeniuszowi, filozofowi, retorowi i egzegecie żyjącemu w VI w. Ekumeniusz napisał kilka komentarzy biblijnych, m.in. komentarz do Apokalipsy w dwunastu tomach, lecz komentarze do listów katolickich znane w obecnej formie pod jego imieniem nie są jego dziełem, gdyż są najprawdopodobniej późniejsze. Możliwe, że miał udział $\mathrm{w}$ ich tworzeniu lub przekazaniu. Przypisania im właściwego autorstwa dokonał w połowie XVI w. Donato Veronese ${ }^{10}$. Choć zatem właściwsze wydaje się nazywanie autora komentarzy Pseudo-Ekumeniuszem, w niniejszym opracowaniu będzie używane jego imię.

- Tractatus in septem Epistolas catholicas (PL Suppl. 3, k. 126-128) Hilarego z Arles, najpierw mnicha, później zaś biskupa w Arles żyjącego w V w. († 449). Komentarz ten zachował się wśród dzieł Hilarego, choć prawdopodobnie w rzeczywistości nie jest jego dziełem, a tylko został mu przypisany. Mógł on powstać w Irlandii na przełomie VII i VIII w. ${ }^{11}$

Można tu wymienić również dzieło Katena do listów katolickich (Catena in Epistolas catholicas) przypisywane Andrzejowi, mnichowi i kapłanowi żyjącemu na przełomie VII i VIII w., choć w rzeczywistości komentarz ten jest nieco później-

9 M. Starowieyski, Beda Czcigodny, w: Encyklopedia katolicka, t. 2, red. F. Gryglewicz, R. Łukaszyk, Z. Sułowski, Lublin 1976, k. 171; T. Skibiński, Listy katolickie..., art. cyt., s. 949; por. R. Grégoire, Beda il Venerabile, w: Dizionario patristico..., vol. 1, dz. cyt., k. 517.

10 F. Drączkowski, Ekumeniusz, w: Encyklopedia katolicka, t. 4, red. R. Łukaszyk, L. Bieńkowski, F. Gryglewicz, Lublin 1983, k. 852-853; T. Skibiński, Listy katolickie ..., art. cyt., s. 947; por. A. Labate, Ecumenio, w: Dizionario patristico..., vol. 1, dz. cyt., k. 10631064.

11 T. Skibiński, Listy katolickie..., art. cyt., s. 948-949; por. L. Gładyszewski, Hilary z Arles, w: Encyklopedia katolicka, t. 6, red. J. Walkusz i in., Lublin 1993, k. 868; S. Pricoco, Ilario di Arles, w: Dizionario patristico..., vol. 1, dz. cyt., k. 1747-1748. 
szy $^{12}$. Choć zatem i w tym przypadku właściwsze wydaje się nazywanie autora komentarzy Pseudo-Andrzejem, w niniejszym opracowaniu występuje jako Andrzej.

Jak zatem widać, w I tysiącleciu chrześcijaństwa powstało niewiele komentarzy do małych listów Janowych. Należy tu zaznaczyć, że nieznana jest ich rzeczywista liczba, nie wiadomo też, czy któreś z nich w ciągu wieków nie zaginęły, przy czym komentarze, które dotrwały do obecnych czasów, niejednokrotnie przetrwały w formie niepełnej lub w tłumaczeniu na inny język.

$2 \mathrm{~J}$ oraz $3 \mathrm{~J}$ to pisma krótkie oraz nie wprowadzające żadnych tematów teologicznych. Klemens Aleksandryjski, komentując $2 \mathrm{~J}$, nazywa go „prościutkim” (semplicissima est $)^{13}$, podobnie można powiedzieć o $3 \mathrm{~J}$. Stąd nasuwa się pytanie: Na co zwracają uwagę ojcowie Kościoła, komentując Drugi i Trzeci List św. Jana? Jakie tematy poruszają i omawiają? Z powodu braku podstaw do bardziej rozbudowanych komentarzy teologicznych ojcowie Kościoła w pierwszej kolejności odnoszą się do tematów historyczno-krytycznych dotyczących okoliczności powstania listów. Tematy poruszane i komentowane przez egzegetów wczesnochrześcijańskich można podzielić na dwie grupy: związane z okolicznościami powstania listów (historycznokrytyczne) oraz związane z tematami pojawiającymi się w treści listów (teologiczne).

\section{Tematy historycznokrytyczne}

Pierwszym tematem, na który zwracają uwagę komentatorzy, jest osoba adresata listów. Drugi List Janowy nie wymienia go z imienia, a list jest zaadresowany do

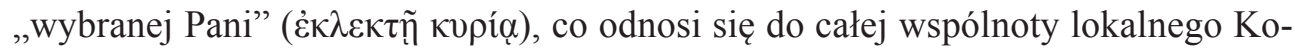
ścioła. Ojcowie Kościoła próbują jednak określić adresata precyzyjniej, doszukując się go w jednej z osób należących do tej wspólnoty. Ekumeniusz, komentując ten fakt (choć nie zgadzając się z nim), stwierdza, że „niektórzy utrzymują, że list ten $[2 \mathrm{~J}]$ jest skierowany do jednej kobiety"14. Klemens Aleksandryjski najpierw stwierdza, że $2 \mathrm{~J}$ został „napisany do dziewic”, żeby za chwilę bardziej precyzyjnie określić, że list ten „,został skierowany do dziewicy babilońskiej o imieniu «Wybrana»". Sam jednak zauważa, że list nie musi być skierowany do indywidualnej osoby, lecz „Imię [Wybrana Pani] oznacza wybranie Kościoła świętego”"15. Tak samo uważa Hilary z Arles, który stwierdza, że „«Wybrana Pani» to zapewne wspólnota Kościoła, do której skierowany jest list”. I dodaje: „Jest ona wybraną w wierze, jak również panią cnót" ${ }^{\prime \prime}$. Obie możliwości bierze pod uwagę mnich Andrzej, który

12 T. Skibiński, Listy katolickie..., art. cyt., s. 947.

13 Clemens Alexandrinus, Adumbrationes in Epistolam II Joannis, Patrologiae Cursus Completus. Series Graeca 9, accurate J.P. Migne, Parisiis 1857, k. 737.

14 Oecumenius, Joannis Apostoli posterior catholica Epistola, Patrologiae Cursus Completus. Series Graeca 119, accurate J.P. Migne, Parisiis 1881, k. 685C.

15 Clemens Alexandrinus, Adumbrationes in Epistolam II Joannis, art. cyt., k. 737-738.

16 Hilarius Arelatensis, Tractatus in septem Epistolas catholicas, Patrologiae Cursus Completus. Series Latina Supplementum 3 (ad vol. 49-66), accurate J.P. Migne, Parisiis 1963, k. 126. 
w swojej Katenie komentuje: „Jan pisze do któregoś z Kościołów bądź do szczególnej niewiasty, która zgodnie ze wskazaniem Ewangelii została ustanowiona duchową opiekunką swojego domu”. Autor ten skłania się jednak ku temu, że „Wybrana Pani" to konkretna osoba, a nie wspólnota kościelna. Wynika to z jego stwierdzenia: „Apostoł, pisząc ten list do wspomnianej niewiasty, która przyjęła naukę, zachęca ją do dwóch rzeczy [...]. Jan mówi, że zasadniczym celem tego listu jest powiadomienie o rychłym jego przybyciu do niej" ${ }^{17}$. Odnosząc się do ostatniego wersu listu, Hilary z Arles jeszcze raz stwierdza, że jego adresatem jest lokalna wspólnota chrześcijan, a nie pojedyncza osoba. Komentując słowa „Dzieci twej Wybranej Siostry ślą ci pozdrowienia”, zauważa: „Jan łączy spokrewnione Kościoły w pokoju. Są one siostrami w wierze, bo w chrzcie stały się córkami Boga" ${ }^{18}$. Ten sam pogląd prezentuje Ekumeniusz, który zdecydowanie orzeka, że „końcowe pozdrowienie «Pozdrawiają Cię dzieci twej siostry» świadczy o tym, że list nie był skierowany do niewiasty, lecz do Kościoła, o czym nikt nie powinien dyskutować"19. Wcześniej natomiast ten sam autor uzasadnia, że „pisząc do «wiernej niewiasty», autor nie ogranicza [liczby adresatów], ponieważ «w Chrystusie ani mężczyzny, ani kobiety już nie rozróżnia» (por. Ga 3,28)"’20.

Trzeci List jest zaadresowany do konkretnej osoby prywatnej, do „umiłowane-

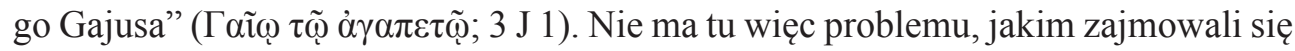
ojcowie, komentując $2 \mathrm{~J}$. Niemniej osobie Gajusa również poświęcają nieco uwagi i miejsca w komentarzach. Mając podane imię adresata listu, komentatorzy próbują jak najprecyzyjniej określić jego osobę. Ekumeniusz podkreśla tylko jego wielką gościnność ( $\varphi \imath \lambda \circ \xi \varepsilon v i ́ \alpha)$ chwaloną w liście: Gajus „czyni dobrze, bo żyje według prawdy Ewangelii” ${ }^{21}$. Ponadto Ekumeniusz stwierdza, że Jan, pisząc do jednego adresata, naśladuje w ten sposób Pawła, który napisał listy do Tytusa, Tymoteusza oraz do Filemona, którego egzegeta określa jako ỉ̇ítᄁ (idiōtēs), czyli osobę prywatną lub laika, osobę nie sprawującą urzędu (w tym wypadku nie będącą biskupem) ${ }^{22}$. Więcej miejsca osobie Gajusa poświęca Beda Czcigodny w swoim komentarzu do 3 J. Pisze on: „Kim był ów Gajus i jakiego rodzaju człowiekiem, ukazane jest w treści listu. Wiarę w Chrystusa wyrażał on w dobrych uczynkach; jeżeli nawet sam głoszeniu słowa niewiele się poświęcał, cieszył się jednak, gdy mógł ze swoich środ-

17 Catena in Epistolas catholicas, red. J.A. Cramer, Oxford 1840; thum. D. Sztuk, za: List św. Jakuba, I-II List św. Piotra, I-III List św. Jana, List św. Judy, red. G. Bray, Ojcowie Kościoła komentują Biblię 11, Ząbki 2014, s. 214.

18 Hilarius Arelatensis, Tractatus in septem Epistolas catholicas, art. cyt., k. 127.

19 Oecumenius, Joannis Apostoli tertia catholica Epistola, Patrologiae Cursus Completus. Series Graeca 119, accurate J.P. Migne, Parisiis 1881, k. 696.

20 Oecumenius, Joannis Apostoli posterior catholica Epistola, art. cyt., k. 688.

${ }^{21}$ Oecumenius, Joannis Apostoli tertia catholica Epistola, art. cyt., k. 697, 700; por. Andrzej, Catena in Epistolas catholicas, red. J.A. Cramer, Oxford 1840; thum. D. Sztuk, za: List św. Jakuba..., dz. cyt., s. 222.

22 Oecumenius, Joannis Apostoli posterior catholica Epistola, art. cyt., k. 688. 
ków wspierać tych, którzy je głoszą"23. Ponadto Beda podejmuje próbę ustalenia tożsamości adresata Trzeciego Listu św. Jana. Stwierdza: „,sądzimy, że jest to ten Gajus, którego Paweł wymienia w Liście do Rzymian, pisząc: «Gajus, który jest gospodarzem moim i całego Kościoła»" (Rz 16,23). Beda Czcigodny, jak sam pisze w swoim komentarzu, ma tu na myśli Gajusa z Koryntu, jednego z nielicznych Koryntian ochrzczonych osobiście przez Pawła Apostoła $(1 \text { Kor } 1,14)^{24}$. Identyfikacja ta jest jednak bardzo mało prawdopodobna, ponieważ imię to było w tym czasie bardzo popularne, ponadto $3 \mathrm{~J} 4$ wskazuje, że Gajus, adresat listu, mógł być ochrzczony lub nawrócony przez Jana Apostoła ${ }^{25}$, co wyklucza jego identyfikację z Gajusem z Koryntu, który swą wiarę i chrzest zawdzięczał Pawłowi ${ }^{26}$. To, na czym mógł oprzeć się Beda Czcigodny w swej hipotezie, to cecha gościnności, która charakteryzuje obie te postacie. Tę właśnie gościnność Gajusa, adresata $3 \mathrm{~J}$, podkreśla Beda w słowach: „Był on gospodarzem całego Kościoła, albowiem jak to cały list przedstawia, wszyscy, którzy do niego przybywali: i przepowiadający, i słuchający słowa, uprzejmie byli przyjmowani" ${ }^{27}$.

Kolejnym tematem, powiązanym z poprzednim, jest omówienie oraz identyfikacja innych osób pojawiających się w omawianych listach. Tak więc Trzeci List Janowy wymienia osobę Demetriusza, przywołując „dobre świadectwo”, jakie dają o nim „wszyscy [...], a nawet sama Prawda”, oraz potwierdzając to świadectwo swoim autorytetem (3 J 12). Mnich Andrzej w swojej Katenie pisze o nim: „Wydaje mi się, że ów Demetriusz jest tym samym, który wytwarzał świątyńki ku czci Arte-

23 Beda Venerabilis, In III Epistolam Joannis, Patrologiae Cursus Completus. Series Latina 93, accurate J.P. Migne, Parisiis 1862, k. 121.

24 Beda Venerabilis, In III Epistolam Joannis, art. cyt., k. 121-122. Według Dz Paweł po odrzuceniu Ewangelii przez Żydów korynckich ,,poszedł do domu pewnego «czciciela Boga», niejakiego Tycjusza Justusa" (Dz 18,7). A zatem tekst NT wymienia dwóch ludzi goszczących Pawła w swoim domu w czasie jego pobytu w Koryncie. Jest możliwe, że chodzi tu o tę samą osobę, której pełne imię brzmiałoby Gajus Tycjusz Justus. Może być też tak, że na początku swej działalności misyjnej w Koryncie Paweł zamieszkał w domu Tycjusza Justusa, natomiast w czasie swego kolejnego pobytu w Koryncie, gdy spędzał tam zimę i kiedy napisał Rz, przebywał w domu Gajusa, gospodarza całego tamtejszego Kościoła. Por. F. Rienecker, G. Maier, Leksykon biblijny, tłum. D. Irmińska, Prymasowska Seria Biblijna, Warszawa 2001, s. 240.

25 Żydowscy rabini i starożytni filozofowie nazywali czasami swoich uczniów swoimi „dziećmi” (por. Ga 4,19). C.S. Keener, Komentarz historyczno-kulturowy do Nowego Testamentu, Prymasowska Seria Biblijna, Warszawa 2000, s. 582.

${ }^{26} \mathrm{Z}$ tego samego powodu podobnie trudno jest utożsamić Gajusa, adresata listu, z innymi postaciami noszącymi to imię i wymienionymi na kartach Dz: z Gajusem z Macedonii (Dz 19,29) oraz z Gajusem z Derbe (Dz 20,4), ponieważ obaj byli towarzyszami i współpracownikami Pawła Apostoła. Por. Encyklopedia biblijna, red. P.J. Achtemeier, Warszawa 1999, s. 311; F. Rienecker, G. Maier, Leksykon biblijny, dz. cyt., s. 240.

27 Beda Venerabilis, In III Epistolam Joannis, art. cyt., k. 121. 
midy i wzniecił powstanie przeciw Pawłowi”28. Demetriusz wymieniony w $3 \mathrm{~J}$ oraz Demetriusz, o którym opowiadają Dz, wykazują różne cechy. Demetriusz, który wytwarzał świątyńki Artemidy, mieszkał w Efezie, był poganinem i wrogiem Ewangelii Chrystusowej, wzniecone zaś przez niego rozruchy były skierowane nie tyle przeciw osobie Pawła, ile raczej przeciw głoszonej przez niego szerzącej się Ewangelii (,powstały niemałe rozruchy z powodu drogi”), która zagrażała prosperowaniu jego interesu (Dz 19,23-27). W 3 J Demetriusz jest chwalony jako chrześcijanin (3 J 12), ponadto adresat listu raczej nie mieszkał w Efezie (bardziej prawdopodobne jest to, że list został napisany w Efezie, gdyż tam według tradycji przebywał Jan Apostoł). Jest wprawdzie możliwe, że poganin Demetriusz nawrócił się i przeprowadził do innego miasta, jednak w hipotezie Andrzeja trudno widzieć coś więcej niż próbę identyfikacji dwóch osób noszących to samo imię i wymienionych na kartach Nowego Testamentu.

Ekumeniusz z kolei, odnosząc się do w. 12 listu („O Demetriuszu wszyscy dobrze świadczą, a nawet sama Prawda”), poprzestaje na stwierdzeniu: „Mówiąc następnie «sama Prawda», Jan pragnie podkreślić, że Demetriusz wprowadza w czyn słowa, które głosi”, komentując krótko, że daje on „najpiękniejsze świadectwo”. Podobnie krótko do tego samego wersu odnosi się Hilary z Arles: „Demetriusz cieszył się dobrą sławą z powodu swoich cnót" ${ }^{29}$. Hilary dodaje tu swą osobistą uwagę: „Niektórzy postrzegają w tym wersie jego krytykę, lecz ja pojąć nie mogę, jak można dokonać takiej interpretacji!"30. Trudno ustalić, o jaką krytykę chodzi i czego ona miałaby dotyczyć, podobnie jak to, czy Hilary odnosi się do komentarzy pisanych, czy do ustnych dyskusji toczonych w swoich czasach. Według Bedy Czcigodnego pochwała Demetriusza jest również wezwaniem skierowanym do Gajusa, aby i on go naśladował ${ }^{31}$.

Inną postacią, która pojawia się na kartach $3 \mathrm{~J}$, jest Diotrefes, o którym autor listu wyraża się negatywnie. Przywołuje jego pychę (,pragnie być pierwszym wśród nich”), przypomina jego „wystąpienia i złośliwe wypowiedzi” oraz piętnuje fakt, że nie przyjmuje (nie uznaje) osoby i nauczania Apostoła oraz odmawia gościny „,braciom", a także zabrania tego innym członkom swojej wspólnoty (3 J 9-10).

Odnosząc się do osoby Diotrefesa, Beda Czcigodny najpierw nazywa go „oszczercą”, a następnie „heretykiem”. To pierwsze określenie pada tam, gdzie Beda komentuje zapowiedź upomnienia Diotrefesa przez Jana po jego osobistym przybyciu na miejsce. Doktor Kościoła poucza: „Słysząc potwarze, nie możemy dać się kierować naszym wadom i naszej własnej złośliwości, aby samych siebie nie zgubić, ale musimy je ze spokojem znosić, aby wzrastała nasza cnota. Czasem jednak należy wziąć w ryzy tego, kto o nas złe rzeczy rozpowszechnia, ponieważ inaczej psują się

${ }^{28}$ Catena in Epistolas catholicas, red. J.A. Cramer, Oxford 1840; thum. D. Sztuk, za: List św. Jakuba ..., dz. cyt., s. 225.

29 Hilarius Arelatensis, Tractatus in septem Epistolas catholicas, art. cyt., k. 128.

30 Oecumenius, Joannis Apostoli tertia catholica Epistola, art. cyt., k. 701.

31 Beda Venerabilis, In III Epistolam Joannis, art. cyt., k. 124. 
niewinne serca tych, którzy mogliby słyszeć o nas dobre rzeczy”. Za takiego właśnie człowieka, który zasługuje na napomnienie, ponieważ jego złe opinie mogą zdeprawować innych, Beda uznaje Diotrefesa i pisze wprost: „Dlatego Jan gani w liście swego oszczercę, który jego przepowiadania nie słucha - choć słyszeć je może i trwa w przewrotnych obyczajach". Porównuje zapowiedź napomnienia Diotrefesa do podobnej zapowiedzi Pawła Apostoła, który zapytał Koryntian, czy „z rózgą ma do nich przybyć" $(1 \text { Kor 4,21) })^{32}$. W podobny sposób zapowiedź upomnienia Diotrefesa komentuje Ekumeniusz, który zastanawia się: „Jeżeli jest przykazanie, aby nie odpłacać złem za zło, to jakie jest uzasadnienie tego [napomnienia]?”. I sam od razu odpowiada: „Mówimy więc, że przykazanie to nie sprzeciwia się temu, kto przeciw nam samym grzeszy, gdyż jeśli przeciw nam grzeszy, to działanie takie niesie zagrożenie dla naszej wiary. Wtedy należy odpłacić takiemu, jak to uczynił i Paweł z Elimasem, który przekraczał drogi Pańskie (por. Dz 13,8-11)"33. Tak więc Ekumeniusz zestawia osobę Diotrefesa i jego działalność z magiem Elimasem i przenosi na osobę Diotrefesa następujące określenia, którymi Paweł ocenia Elimasa: „syn diabelski, człowiek pełen wszelkiej zdrady i wszelkiej przewrotności, wróg wszelkiej sprawiedliwości, człowiek wykrzywiający proste drogi Pańskie" (por. Dz 13,10). Sam Ekumeniusz określa Diotrefesa słowami: „,niegodziwy i hańbiący ludzkość ( $\varphi \alpha v \lambda o ́ \tau \eta \tau o \varsigma$

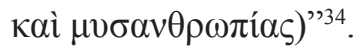

Trzeci List św. Jana stwierdza, że Diotrefes „złośliwie występuje i wypowiada się przeciw nam”, ponadto „tym, którzy chcą ugościć braci, zabrania, a nawet wyklucza ich z Kościoła" (por. 3 J 10). Choć list nie precyzuje, co zawierały wypowiedzi Diotrefesa, komentatorzy przypisują mu herezję i wykluczają go z Kościoła Chrystusowego, analogicznie jak on wykluczał dobrych ludzi z Kościoła lokalnego. Beda Czcigodny pisze wprost: „Diotrefes był jednym z heretyków tamtego czasu. Wyniosły i zuchwały, uzurpował sobie władzę, głosząc nową naukę i nie słuchając w pokorze przykazań, które Jan głosił w Kościele świętym"35.

Oczywiście Diotrefes nie był jedynym heretykiem tamtego Kościoła i tamtego czasu. Tak twierdzi na przykład Ekumeniusz, który komentuje: „[wszystkim] podobnym Diotrefesowi Jan mówi, że są oni oddzieleni od prawdy i nie znają Boga"36. Beda Czcigodny uważa, że także teksty $2 \mathrm{~J}$ odnoszą się do heretyków, zapewne działających w mieście adresatów 2 J i 3 J. Komentując słowa 2 J 5 („A teraz proszę cię, Pani, abyśmy się wzajemnie miłowali”), doktor Kościoła stwierdza: „Jest to słowo przeciw heretykom, którzy próbują wprowadzać nowy dogmat, którego szczątki usłyszeli od apostołów, a przez to osłabiają więzy braterskiej miłości" ${ }^{37}$.

32 Beda Venerabilis, In III Epistolam Joannis, art. cyt., k. 124.

33 Oecumenius, Joannis Apostoli tertia catholica Epistola, art. cyt., k. 700.

34 Oecumenius, Joannis Apostoli tertia catholica Epistola, art. cyt., k. 697.

35 Beda Venerabilis, In III Epistolam Joannis, art. cyt., k. 124.

36 Oecumenius, Joannis Apostoli tertia catholica Epistola, art. cyt., k. 697.

37 Beda Venerabilis, In II Epistolam Joannis, Patrologiae Cursus Completus. Series Latina 93, accurate J.P. Migne, Parisiis 1862, k. 121. 
Wśród heretyków ówczesnej doby Beda wymienia Marcjona i Kerynta, którzy żyli i działali w II w., a więc już po śmierci Jana Apostoła. Słowa listu nie mogą się do nich odnosić, w komentarzu są to raczej przykładowe imiona i symbole postawy heretyckiej, odrzucającej prawdę Ewangelii. Również określenia „Zwodziciele” oraz „antychryst”, które pojawiają się w $2 \mathrm{~J}$ 6, Beda utożsamia z heretykami, tym razem jednak nie tylko z nimi, lecz również z żydami, którzy nie przyjęli wiary w Jezusa Chrystusa. Odnosi on ten wers w pierwszym rzędzie do heretyków, „którzy wprawdzie uznawali wcielenie Jezusa Chrystusa, lecz opacznie thumaczyli prawdy wiary odnoszące się do Niego. Przeczyli więc, że miał On prawdziwe ciało i prawdziwą duszę. [...] oraz jeszcze innym prawdom, które znajdują się w wyznaniu prawdziwej wiary”. Beda widzi jednak tutaj odniesienie także do żydów, którzy „,absolutnie negują Jezusa Chrystusa i zaklinają się, że Chrystus w ciele jeszcze nie przyszedł dla naszego zbawienia, ale na swoją zagładę oczekują przyjścia Antychrysta" ${ }^{38}$. Inaczej formułuje to Hilary z Arles, który w swym komentarzu stwierdza, że w $2 \mathrm{~J}$ „Jan ostrzega, by nie popaść w herezję tuż po wkroczeniu na drogę wiary oraz by nie powracać z Nowego Testamentu do Starego"39.

Kolejne osoby wspomniane w 2-3 J to grupa określona ogólnym określeniem „wszyscy” w zdaniu: „O Demetriuszu wszyscy dobrze świadczą” (3 J 12). Zatrzymując się nad tą grupą ludzi, Ekumeniusz opisuje ich tak: „Jan, mówiąc «wszyscy», ma w tym miejscu na myśli wszystkich, którzy przestrzegają prawdy. Niewykluczone, że wyrażenie to obejmuje także niewierzących, bo i Paweł starał się przypodobać Żydom oraz Grekom" "40. Ekumeniusz nawiązuje tutaj do słów Pawła Apostoła zapisanych w Pierwszym Liście do Koryntian: „Nie bądźcie zgorszeniem ani dla Żydów, ani dla Greków, ani dla Kościoła Bożego, podobnie jak ja, który się staram przypodobać wszystkim" (1 Kor 10,32-33); oraz do Pawłowej zasady, żeby w życiu wspólnoty mieć na względzie również osoby określane jako „ci na zewnątrz”, czyli niechrześcijan pozostających na zewnątrz wspólnoty Kościoła, aby „wobec nich postępować szlachetnie" (1 Tes 4,12), a nawet przy wyborze biskupa uwzględniać to, że „powinien też mieć dobre świadectwo z ich strony $(1 \mathrm{Tm} 3,7)^{41}$. Taką myśl wyraża również Dydym Ślepy w swym komentarzu do $2 \mathrm{~J}$, stwierdzając, że dobre życie chrześcijan przekonuje do tego samego także innych, ,tego, który jest na ze-

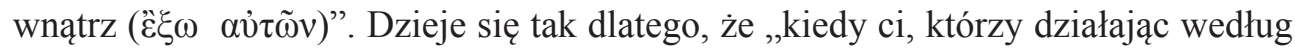

38 Beda Venerabilis, In II Epistolam Joannis, art. cyt., k. 121. Słowo ,żydzi” odnosi się do wspólnoty religijnej, a nie do narodowej, dlatego w pracy pisane jest ono małą literą. W komentarzu Bedy słowo to napisane jest wielką literą (de Judaeis), tym niemniej czytelne jest, że jego określenie jest właściwe dla tych Żydów, którzy odrzucili Chrystusa, a nie ludzi narodowości hebrajskiej.

39 Hilarius Arelatensis, Tractatus in septem Epistolas catholicas, art. cyt., k. 126.

40 Oecumenius, Joannis Apostoli tertia catholica Epistola, art. cyt., k. 701.

41 Sprawa autorstwa $1 \mathrm{Tm}$ jest osobną kwestią. Niezależnie od tego, kto dokładnie jest autorem tego listu, należy zauważyć, że nawet jeżeli wyraża on poglądy szkoły Pawłowej, to są one sformułowane w duchu nauczania samego Pawła Apostoła. 
przykazań, praktykują cnoty, wtedy postępuje według nich i ten, kto ich nie ma i jest na zewnątrz" ${ }^{42}$.

W tym wątku należy poruszyć również sprawę autora listów. Nie jest on tu wymieniony z imienia. Utożsamia się go z Janem Apostołem i Ewangelistą, ale nie jest to identyfikacja uznawana jednomyślnie. Ponieważ przedstawia się on jako „prezbiter” (ó $\pi \rho \varepsilon \sigma \beta\langle ́ \tau \varepsilon \rho \circ \varsigma$ ), określany jest również jako Jan Prezbiter różny od Jana Apostoła. Jako pewnik egzegeci starożytni przyjmują fakt, że i $2 \mathrm{~J}$ i $3 \mathrm{~J}$ zostały napisane przez jednego autora i powstały razem przy jednej okazji. Odnosząc się do zwięzłości pozdrowienia w $3 \mathrm{~J}$, Ekumeniusz tłumaczy, że pozdrowienie w $3 \mathrm{~J}$ ma taką formę, ponieważ ,podobne pozdrowienie jest w poprzednim [liście], teraz zatem powtarzać to samo byłoby czymś zbytecznym i nadmiernym"³ . Również mnich Andrzej w swojej Katenie wymienia Jana jako autora zarówno $2 \mathrm{~J}$, jak i $3 \mathrm{~J}$, pisząc: „Jan pochwala też Demetriusza [...]. Powód napisania tego listu jest więc taki sam jak poprzedniego""44.

Odnosząc się do wątpliwości i dyskusji dotyczących autorstwa 2 J i 3 J, Beda Czcigodny odnotowuje: „Niektórzy myślą, że autorem i tego, i następnego listu jest nie Jan Apostoł, lecz pewien prezbiter Jan, którego grób aż do dziś jest pokazywany w Efezie. Wspomina o nim Papiasz, słuchacz apostołów. Ale dziś w Kościele powszechnym istnieje konsensus, że to Jan Apostoł napisał te listy. Znajdujemy w nich słownictwo podobne do tego w Pierwszym Liście i widzimy podobną gorliwość w przeciwstawianiu się herezji” ${ }^{45}$. Również Ekumeniusz przekonuje: „Niektórzy twierdzą, że ten list i następny nie zostały napisane przez Jana, umiłowanego ucznia Pańskiego, lecz przez inną osobę o tym samym imieniu. W obydwu bowiem listach autor przedstawia się jako prezbiter i kieruje swoje słowa do jednego adresata, podczas gdy w pierwszym liście powszechnym tego nie czyni. Ponadto w obu wspomnianych listach rozpoczyna od osobistego wstępu, którego brakuje w liście pierwszym. Ale my mówimy, że Jan w swoim pierwszym liście nie umieścił takiego wstępu, ponieważ nie pisał do znanej mu osoby ani do konkretnej wspólnoty Kościoła" ${ }^{46}$. Ekumeniusz zauważa tu również, że podobnie ma się rzecz z listami Piotra i Jakuba, które również nie są pisane do indywidualnej osoby, lecz do wspólnoty. Natomiast odnosząc się do faktu, że autor listu nie przedstawia się jako apostoł, wyjaśnia: „Z kolei fakt, że przedstawia się on jako prezbiter, a nie jako apostoł, jest podyktowany tym, że nie był on pierwszym misjonarzem, który głosił Ewangelię w Azji, przed nim bowiem przybył tam Paweł. Niemniej w przeciwieństwie do swego wielkiego poprzednika, który jedynie przemierzył ten region, Jan pozostał dłużej i głosił słowo bezpośrednio ludziom tam mieszkającym. W liście swym nie

42 Didymus Alexandrinus, In Epistolam divi Joannis sedundam enarratio, Patrologiae Cursus Completus. Series Graeca 39, accurate J.P. Migne, Parisiis 1863, k. 1809.

43 Oecumenius, Joannis Apostoli tertia catholica Epistola, art. cyt., k. 700.

44 Catena in Epistolas catholicas, red. J.A. Cramer, Oxford 1840; thum. D. Sztuk, za: List św. Jakuba..., dz. cyt., s. 222.

45 Beda Venerabilis, In II Epistolam Joannis, art. cyt., k. 119.

${ }^{46}$ Oecumenius, Joannis Apostoli posterior catholica Epistola, art. cyt., k. 685. 
przedstawia się jako sługa Chrystusa, ponieważ jako umiłowany uczeń pamiętał, że został nazwany przyjacielem Pana" ${ }^{47}$. Ponadto egzegeta zauważa, że ówczesny tytuł „prezbiter” oznacza to samo, co w jego czasach „biskup”, powołując się przy tym na to, co napisał „błogosławiony Łukasz” oraz „Apostoł Piotr”. Ekumeniusz miał na myśli teksty Dz 20,17 oraz 1 P 5,1-4, gdzie choć znajduje się słowo „prezbiter”, ewidentnie mowa jest o zwierzchnikach wspólnoty chrześcijańskiej ${ }^{48}$. Także Beda Czcigodny uzasadnia użycie tego właśnie słowa przez autora listu: „Kiedy Jan pisał ten list, był zaawansowany wiekiem i dlatego używa nazwy «starszy», czyli prezbiter". I również odwołuje się do słów Pierwszego Listu św. Piotra Apostoła „Starszych, którzy są wśród was, proszę ja, również starszy" (1 P 5,1 $)^{49}$.

Za Janowym autorstwem tych listów przemawia to, że tematy w nich poruszone pojawiają się również w Pierwszym Liście św. Jana. Argument ten przywołuje Ekumeniusz, który odnosząc się do określenia Gajusa („którego miłuję w prawdzie” - 3 J 1), pisze: „Kto miłuje Boga szczerą miłością, ten miłuje Go w prawdzie. Oto temat, który Jan często porusza w swoich listach" ${ }^{50}$. Również komentując słowa 2 J 5 (,A teraz proszę cię, Pani, abyśmy się wzajemnie miłowali”), Ekumeniusz zauważa: „Zwróć uwagę, że nauka zawarta w tym liście współbrzmi ze słowami pierwszego listu Jana: wiemy, że kto miłuje Boga, przykazań Jego przestrzega" (por. 1 J 5,2-3) ) $^{51}$.

\section{Komentarze teologiczne}

Tematy teologiczne obecne w treści Drugiego i Trzeciego Listu św. Jana i poruszane w komentarzach ojców Kościoła da się podzielić na trzy grupy: związane z Chrystusem, związane z wiarą i prawdą wiary oraz związane z życiem wspólnoty Kościoła (bardziej lokalnej wspólnoty adresatów listów niż całego Kościoła powszechnego).

Rozpoczynając od osoby Jezusa Chrystusa, można zauważyć, że komentatorów zajmowała Jego relacja z Bogiem Ojcem. Odnosząc się do słów pozdrowienia „,pokój Boga Ojca i Jezusa Chrystusa, Syna Ojca" (2 J 3), Beda Czcigodny przypomina najpierw, że „heretycy tamtych czasów, Marcjon i Kerynt, negowali, że Pan nasz, Jezus Chrystus, jest Synem Boga, i przyznawali, że Jego początek to Jego ludzkie narodziny”. I od razu komentuje: „Jan daje świadectwo bycia wiernym Bogu Ojcu i ukazuje Jezusa Chrystusa równym i współwiecznym (aequalem et coaeternum) Ojcu. Określa też, że Jego [Syna] dary są takie same jak Ojca, jak to sam Pan nasz o swojej i Ojca wspótistotności (consubstantialitate) mówi: «Co bowiem Ojciec czyni, tak i Syn czyni podobnie» (por. J 5,19)"52. To samo podkreśla Klemens Aleksandryjski, który w swym komentarzu stwierdza, że „kto ma w swoim umyśle jasny

${ }^{47}$ Oecumenius, Joannis Apostoli posterior catholica Epistola, art. cyt., k. 685-687.

48 Oecumenius, Joannis Apostoli posterior catholica Epistola, art. cyt., k. 687.

49 Beda Venerabilis, In II Epistolam Joannis, art. cyt., k. 119-120.

50 Oecumenius, Joannis Apostoli tertia catholica Epistola, art. cyt., k. 700.

51 Oecumenius, Joannis Apostoli posterior catholica Epistola, art. cyt., k. 689.

52 Beda Venerabilis, In II Epistolam Joannis, art. cyt., k. 121. 
obraz Syna, ten i Ojca zarazem poznaje, a także obejmuje swym umysłem wielkość Jego działania, które jest bez początku czasu"53. Prawdę o współistotności Ojca i Syna Dydym Ślepy dostrzega również w innych słowach tego listu, gdzie Apostoł pisze, że „kto trwa w nauce [Chrystusa], ten ma i Ojca, i Syna” (2 J 9). Asceta pisze: „Kto ma, mówi, Syna, ma i Ojca; i odwrotnie, przez co naturalnie się pojmuje, że [Syn] jest tą samą boską substancją. Ponieważ rzeczywiście Ojciec jest w Synu, ten, kto ma Syna, ma i Ojca; co również jest prawdą w drugą stronę: bo kto ma Ojca, ma Syna, który jest w Ojcu" 54 .

Z kolei Ekumeniusz, odnosząc się do słów: „,przykazanie, jakie otrzymaliśmy od Ojca” (2 J 4), stwierdza, że słowo „Ojciec” odnosi się w tym przypadku nie do Boga Ojca, ale do Syna Bożego, Jezusa Chrystusa. Pisze więc: „Przykazanie Ojca, do którego Jan się odnosi, jest zapisane w Ewangelii. Sam Chrystus mówi: «Kto ma przykazania moje i zachowuje je, ten Mnie miłuje»” i uzasadnia: „Ojcem Jan nazywa Chrystusa, ponieważ jest On rzeczywiście ojcem wszystkich dzieci, które zostały Mu powierzone z zamysłu samego Ojca, bo powiedział: «Oto ja i dzieci moje, które dał mi Ojciec» (por. J 10,29; 13,33; 21,5)" "55. Ekumeniusz nie sprzeciwia się tu Bedzie ani prawdzie wiary, komentuje bowiem inny tekst $2 \mathrm{~J}$ i nie odnosi się do osoby Boga Ojca. Egzegeta łączy tu wypowiedź Chrystusa zapisaną w Ewangelii z tekstem $2 \mathrm{~J}$ poprzez powtarzające się w obu tekstach słowo „przy-

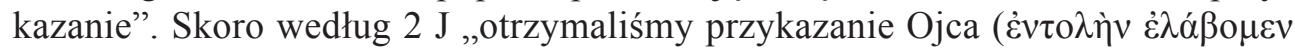
$\pi \alpha \rho \alpha \grave{~} \tau o \tilde{v} \pi \alpha \tau \rho o ́ \varsigma)$ ”, a według Ewangelii Chrystus daje uczniom ,przykazania moje

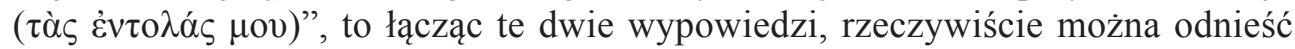
określenie „Ojciec” do Chrystusa.

O „przykazaniach Jezusa” pisze także Dydym Ślepy, który przestrzega, że „kto jest poza prawdziwą wiarą i słuchaniem przykazań Jezusa, jest bez Boga”. Przykazania te nie są jednak tylko „Jezusa”, ponieważ w kolejnym zdaniu Dydym, pisząc o ,przykazaniach Jego” oraz o „przykazaniach Boga”, określa jako ich autora zarówno Syna Bożego, jak i Boga Ojca we wspólnym ich działaniu. Jedność Chrystusa z Ojcem i tożsamość ich działania Dydym podkreśla również w słowach: „do tego, który służy przykazaniom Jego, mówi Syn, Ojciec z Nim przyjdzie [do tego], kto rzeczywiście świątynię świętą zbudował przez przestrzeganie Bożych przykazań" i cytuje: ,jak mówi list: «kto trwa w Nim, ma Ojca i Syna»" ${ }^{56}$. Ekumeniusz zwraca uwagę na fakt, że Jan w tym miejscu ,wymienia tylko Ojca i Syna, pomija zaś Ducha Świętego". Według egzegety nie powinno to gorszyć czytelnika, ponieważ słowa te pojawiają się w kontekście tematu herezji chrystologicznej, a zatem wypowiedź Apostoła wymaga odniesienia się tylko do Ojca i Syna, dlatego Duch Święty nie jest tam wymieniony ${ }^{57}$.

53 Clemens Alexandrinus, Adumbrationes in Epistolam II Joannis, art. cyt., k. 739.

54 Didymus Alexandrinus, In Epistolam divi Joannis sedundam enarratio, dz. cyt., k. 1810.

55 Oecumenius, Joannis Apostoli posterior catholica Epistola, art. cyt., k. 689.

56 Didymus Alexandrinus, In Epistolam divi Joannis sedundam enarratio, dz. cyt., k. 1810.

57 Oecumenius, Joannis Apostoli posterior catholica Epistola, art. cyt., k. 693. 
Inny temat związany z osobą Chrystusa dotyczy Jego przyjścia na ten świat, charakteru i właściwości tego przyjścia. Komentarze odnoszą się do słów: „Wielu bowiem pojawiło się na świecie zwodzicieli, którzy nie uznają, że Jezus Chrystus przyszedł w ciele ludzkim" (2 J 7). Beda Czcigodny w swoim komentarzu odnosi te słowa „do heretyków”, do których „można zaliczyć i tych, którzy wyznają wcielenie Jezusa Chrystusa, ale inną część wiary niewłaściwie pojmują", a więc niekoniecznie do wrogów wiary chrześcijańskiej, lecz także do tych, którzy pobłądzili w rozumieniu i tłumaczeniu wydarzeń zbawczych (co nie zmienia oczywiście faktu, że z tego powodu są heretykami). I przytacza błędne poglądy takich ludzi: „,czy to prawdziwe Jego ciało, czy prawdziwą duszę, czy prawdziwą boskość, czy prawdziwego Jego Ojca, Boga, czy prawdziwego Jego Ducha Świętego Boga wszechmogącego, czy też inne rzeczy negują, które należą do prawdziwej wiary"58. W komentarzu Bedy widać jasno, że przemawia on, znając rozstrzygnięcia późniejszych dyskusji teologicznych oraz orzeczenia synodów i soborów powszechnych. List Janowy wyraźnie mówi o ludziach zaprzeczających przyjściu Syna Bożego w ciele ludzkim, ale nic nie mówi o Jego duszy ani o Duchu Świętym. Dla Bedy jeden heretycki pogląd wyrażony w $2 \mathrm{~J}$ jest więc okazją do wymienienia kilku innych błędów dotyczących wcielenia Chrystusa, co może bardziej odnosi się do czasów Bedy niż do czasu pisania $2 \mathrm{~J}$.

Beda zauważa również, że takie samo podejście do wcielenia Syna Bożego mieli żydzi, dlatego również i do nich mogą odnosić się określenia „zwodziciel i antychryst" użyte przez autora listu. Żydzi nie uznali Mesjasza, który już przyszedł, i oczekują Go nadal. Ich oczekiwanie jest oczywiście próżne, ponieważ nie doczekają się tego, który już przyszedł; jedyną osobą, której się doczekają, jest zatem nie Mesjasz-Chrystus, ale Antychryst, i to na niego w rzeczywistości czekają. Odnosząc się do żydów, Beda stwierdza, że „absolutnie negują Jezusa Chrystusa i zaklinają się, że Chrystus (czyli Mesjasz) nie przyszedł jeszcze w ciele dla naszego zbawienia, ale na swoją zagładę oczekują przyjścia Antychrysta" ${ }^{59}$. Również Klemens Aleksandryjski uważa, że Jan w swoim liście chce umocnić adresatów, ,aby nikt nie dzielił Jezusa Chrystusa, ale aby każdy wierzył, że Jezus Chrystus przyszedł w ciele" ${ }^{00}$.

Na temat przyjścia Jezusa Ekumeniusz zaskakująco stwierdza, że autor 2 J, mówiąc o przyjściu Jezusa w ciele ludzkim, ma na myśli nie pierwsze, ale drugie przyjście Syna Bożego. Stwierdza bowiem: „Jan, pisząc: «Kto nie uznaje, że Jezus przychodzi w ciele», ewidentnie odnosi się do drugiego przyjścia Pana, bo Pan sam zapowiedział: «Wielu przyjdzie pod moim imieniem». Nie mówi zatem o pierwszym Jego przyjściu, lecz o powtórnym. Ktokolwiek zaprzecza Jego powtórnemu przyjściu, tym samym nie uznaje pierwszego. Jeśli z kolei ktoś uznaje, że Chrystus przyszedł w ciele, to uwierzy również w spełnienie obietnicy Jego powtórnego przyjścia" ${ }^{61}$. Przyczyną takiego twierdzenia jest fakt, że przyjście Jezusa w ciele jest określone w Drugim Liście

\footnotetext{
58 Beda Venerabilis, In II Epistolam Joannis, art. cyt., k. 121-122.

59 Beda Venerabilis, In II Epistolam Joannis, art. cyt., k. 122.

${ }^{60}$ Clemens Alexandrinus, Adumbrationes in Epistolam II Joannis, art. cyt., k. 739.

${ }^{61}$ Oecumenius, Joannis Apostoli posterior catholica Epistola, art. cyt., k. 692.
} 
Janowym greckim słowem w formie participium praesens ( $\dot{\varepsilon} \rho \chi 0$ $\mu \varepsilon v o v-$ dosł. „, nie uznając Jezusa przychodzącego w ciele"), które z gramatycznego punktu widzenia rzeczywiście nie musi odnosić się do wydarzenia przeszłego. Sam egzegeta przekonuje, że „umiłowany uczeń” rozmyślnie pisze „przychodzący” (غ่ $\rho \chi o ́ \mu \varepsilon v o v)$, a nie „przyszedł" ( $\dot{\lambda} \lambda \theta o ́ v \tau \alpha)$, aby zaznaczyć, że obydwa przyjścia Chrystusa dokonają się w ciele

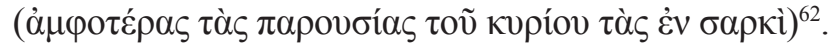

Do tej prawdy wiary odnosi się również Ekumeniusz, komentując słowa następnego wersu listu Janowego, przestrzegające: ,abyście nie utracili tego, co zdobyliście pracą, lecz żebyście otrzymali pełną zapłatę" (2 J 8). Filozof pyta w swoim komentarzu: „A gdybym nie uwierzył w przyjście ( $\pi \alpha \rho o v \sigma i ́ \alpha)$ Chrystusa w ciele? Czyż za samo wypełnienie życia dobrymi czynami, dzięki spełnianym uczynkom nie będę postawiony w jednym szeregu ze sprawiedliwymi i nie otrzymam nagrody?”. I odpowiada na tak postawione pytanie: „Jak może liczyć na osiągnięcie tego, co przynależy wiernym albo na nazwanie bogobojnym ten, kto neguje przyjście Pana w ciele? Żaden przekraczający przykazanie Chrystusa, który przychodzi, i nie trwający w Jego nauce, nie ma Boga" ${ }^{63}$. Egzegeta porusza tu ważny temat obecny w listach Nowego Testamentu: czy zbawienie człowieka zależy od jego wiary, czy od jego uczynków (por. Ga 2,16; Rz 3,24; Jk 2,18)? Nie przytaczając oczywiście całej dyskusji na ten temat, przypomina, że same czyny bez przyjmowania prawd wiary nie pozwolą osiągnąć ,wieczystej nagrody świętych”. Oczywiście sama wiara bez uczynków i działania też nie zda się na wiele, jak zauważa Dydym Ślepy, który działanie (postępowanie) według cnoty ( $\left.\kappa \alpha \tau^{\prime} \dot{\alpha} \rho \varepsilon \tau \eta \nu ~ \varepsilon ่ v \varepsilon \rho \gamma \varepsilon \tilde{v}\right)$ stawia jako warunek przestrzegania przykazań. Dzieje się tak dlatego, że „rozwijanie się według cnoty” charakteryzuje „męża doskonałego”, a takie określenie przysługuje właśnie temu, kto przestrzega przykazań ${ }^{64}$. Ową „drogę cnoty” Ekumeniusz opisuje, że jest ona

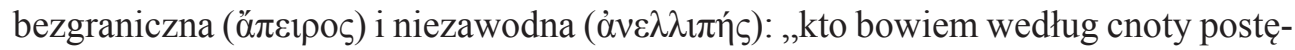
puje, zyskuje sobie większe dobra". Aby ukazać wielkość możliwych do uzyskania w ten sposób darów, egzegeta do owej „drogi cnoty” odnosi słowa Pierwszego Listu św. Piotra: „wejrzeć w te sprawy pragną aniołowie” (1 P 1,12) i podsumowuje: „taki jest ogrom darów dobroci, jakie człowiek zyskał przez wcielenie Jezusa, że pragnieniem aniołów jest, aby nabyli choć trochę zrozumienia tych rzeczy" ${ }^{95}$. Konieczność jedności wiary i czynów człowieka przedstawia krótko Beda Czcigodny, odnosząc się do postawy Gajusa (3 J 5): „«Wiernie czynisz», mówi, żeby powiedzieć: jak prawdziwie jesteś wierny, tak czyń, pokazując przez czyny wiarę twoją"66.

Przechodząc do tematów związanych z wiarą i prawdą wiary, można zacząć od wypowiedzi Hilarego z Arles. Słowa pozdrowienia 2 J: „prawda, która w nas trwa” (2 J 2), komentuje on tak: „Jan, używając słowa «prawda», ma na myśli Ducha

${ }^{62}$ Oecumenius, Joannis Apostoli posterior catholica Epistola, art. cyt., k. 692.

63 Oecumenius, Joannis Apostoli posterior catholica Epistola, art. cyt., k. 693.

64 Didymus Alexandrinus, In Epistolam divi Joannis sedundam enarratio, dz. cyt., k. 1809.

65 Oecumenius, Joannis Apostoli posterior catholica Epistola, art. cyt., k. 689.

${ }^{66}$ Beda Venerabilis, In III Epistolam Joannis, art. cyt., k. 123. 
Świętego, ponieważ miłość jest zawsze dziełem Ducha"67. Hilary nawiązuje tu do słów Ewangelii Janowej, która przekazuje Chrystusową zapowiedź posłania Ducha (Parakleta) na apostołów, który to Paraklet jest tam nazwany Duchem Prawdy (J 15,26; 16,13). Podobne połączenie miłości i prawdy, choć tym razem określające działanie człowieka, a nie Boga, prezentuje Ekumeniusz w komentarzu do $3 \mathrm{~J}$ 1: „Kto miłuje Boga szczerą miłością, ten miłuje Go w prawdzie"68.

Odnosząc się do postępowania Gajusa w prawdzie, które chwali autor 3 J, Hilary z Arles precyzuje, że prawda to nie tylko teoretyczne rozważania i wywody intelektualne, ale również postawa życiowa, która realizuje się w podejmowanych decyzjach i czynach konkretnej osoby. Kierując swe słowa do czytelnika, pisze zatem: „Prawda twego życia odzwierciedla się w doskonałości twoich uczynków. Postępujesz w prawdzie, gdy czynisz wszystko bez podstępu w myślach, słowach i uczynkach oraz troszczysz się o to, by zachować wszystkie przykazania Boga"69. Podobnie utożsamia prawdę z postawą życiową Beda Czcigodny, łącząc ponadto prawdę z przekazywaniem prawdy Ewangelii i życiem według tej nauki. Stwierdza on w swoim komentarzu: „Dla Jana nie ma większej radości nad tę, gdy słyszy, że dzieci jego postępują w prawdzie, to znaczy kiedy się dowiaduje, że ci, którym głosił słowo Boże bądź udzielił chrztu, zachowują prawdziwą i nienaruszoną wiarę i spełniają dobre uczynki" ${ }^{\prime}$.

To samo połączenie przedstawia w swym komentarzu Ekumeniusz, wyrażając jednocześnie opinię, że „postępowanie w prawdzie” oznacza dokonywanie postępu duchowego, a nie prostą, bierną deklarację wiary. Odnosząc się do tego samego tekstu 3 J, Ekumeniusz obrazowo wyjaśnia: „«Postępować» nie oznacza poruszać nogami z miejsca na miejsce, będąc jedną z istot żywych mających stopy, ale jest to uporządkowany i roztropny pochód według poruszeń duszy". Nie jest to łatwe zadanie, dlatego też egzegeta zauważa również, że „nieliczni nawet spośród mających intelekt potrafią to zrobić"

Z tematem tym łączy się kolejne zdanie komentowane przez ojców Kościoła: „Kto nie trwa w nauce Chrystusa, ten nie ma Boga. Kto trwa w nauce [Chrystusa], ten ma i Ojca, i Syna" (2 J 9). Dla komentatorów bowiem nauka Chrystusa i prawda to pojęcia tożsame. Toteż Beda Czcigodny apeluje: „Zauważ różnicę słów i przyjmij prawdę wiary. Nie ma Boga ten, kto nie trwa w nauce Chrystusa; kto natomiast trwa w Jego nauce, ten ma Syna i Ojca - mówi [Jan], aby ukazać, że Ojciec i Syn są jednym prawdziwym Bogiem (ut ostendat Patrem et Filium unum esse Deum verum), a oskarża o kłamstwo tych, którzy dowodzą, że albo Syn nie jest Bogiem, albo jest późniejszy lub mniejszy od Ojca”72. Natomiast Ekumeniusz przekonuje: „Trwa w nauce Chrystusa, czyli Ewangelii, kto według niej myśli i działa, kto zaś ją odrzu-

${ }^{67}$ Hilarius Arelatensis, Tractatus in septem Epistolas catholicas, art. cyt., k. 126.

${ }_{68}$ Oecumenius, Joannis Apostoli tertia catholica Epistola, art. cyt., k. 700.

69 Hilarius Arelatensis, Tractatus in septem Epistolas catholicas, art. cyt., k. 127.

70 Beda Venerabilis, In III Epistolam Joannis, art. cyt., k. 123.

71 Oecumenius, Joannis Apostoli tertia catholica Epistola, art. cyt., k. 700.

${ }^{72}$ Beda Venerabilis, In II Epistolam Joannis, art. cyt., k. 122. 
ca, jest ateistą i sam siebie odłącza od posiadania Boga". Takiemu ateiście (ö $\theta \varepsilon o \varsigma)$ Ekumeniusz przeciwstawia człowieka będącego „w Bogu” ("̌v $\theta \varepsilon \circ \varsigma)$. Zaznaczając różnicę między nimi, tłumaczy te nazwy, pisząc, że ateista jest człowiekiem „bez Boga”, natomiast człowiek „w Bogu”, ,jest przyjacielem Boga i ma w sobie pełnię całej boskości, czyli Ojca, Syna i Ducha Świętego, i jest stały w nauce Chrystusa"73.

A zatem należy odróżnić i oddzielić od chrześcijan tych, którzy nauki Chrystusa nie głoszą albo wręcz ją odrzucają. Komentatorzy stwierdzają, że do takich ludzi odnosi się tekst $2 \mathrm{~J}$ 10-11: ,Jeśli ktoś przychodzi do was i tej nauki nie przynosi, nie przyjmujcie go do domu i nie pozdrawiajcie go, albowiem kto go pozdrawia, staje się współuczestnikiem jego złych czynów". Hilary z Arles stwierdza wprost: „Oto przykład ekskomuniki w Nowym Testamencie, która wyklucza wiarołomców z udziału we wspólnych posiłkach, z Eucharystii i z daru komunii Kościoła"74. Także Dydym Ślepy zauważa: „Trwa w nauce Ewangelii ten, kto ją docenia i wprowadza w czyn, a nadto stroni od osób, które podążają inną drogą"75. Beda Czcigodny, komentując pozdrowienie końcowe $3 \mathrm{~J}$ („Pozdrów imiennie każdego z przyjaciół”), stwierdza: „[Jan] posyła życzenie pokoju oraz pozdrowienie „przyjaciołom”, aby przez [takie sformułowanie] pokazać Diotrefesowi i podobnym jemu nieprzyjaciołom prawdy, że są oni pozbawieni pozdrowienia i życzenia pokoju przeznaczonego dla adresatów" "76. To samo przesłanie Beda Czcigodny znajduje w zakończeniu $2 \mathrm{~J}$ oraz $\mathrm{w}$ pozdrowieniu tego listu. Według niego Jan przypomina, że jest jedna miłość w Duchu Świętym, aby „oddzielić tych, którzy są złączeni z heretykami, a którzy osłabiają jednomyślność katolików”, oraz że Jan ,jak przeciwników prawdy zakazał pozdrawiać, tak przeciwnie, pozdrawia wybranych"77.

Beda przywołuje też dwa wydarzenia, w których uczestniczą owi heretycy oraz Polikarp, uczeń Jana Apostoła. Wydarzenia te mają podkreślić, że od takich osób należy się zdecydowanie odciąć. Jak pisze: „Opowiada o nich słuchacz jego, najświętszy i świadek najsilniejszy, Polikarp, biskup Smyrny. On w tym czasie w Efezie wszedł do kąpieli i zobaczywszy tam Kerynta, wyskoczył natychmiast i odszedł bez kąpieli, mówiąc: «Uciekamy, aby nie kontynuować tej kąpieli, w której myje się Kerynt, nieprzyjaciel prawdy». Podobnie, kiedy Marcjon mówił do niego: «Uznaj nas!», Polikarp odpowiedział: «Uznaję, uznaję za pierworodnego szatana». Tak więc apostołowie i ich uczniowie zachowywali ostrożność w sprawach religii, aby nawet słowem nie mieć nic wspólnego z tymi, którzy wykrzywiali prawdę, jak to i Paweł powiedział: «Od sekciarza odsuń się po pierwszym lub po drugim upomnieniu, wiedząc, że człowiek taki jest przewrotny i grzeszny, przy czym sam na siebie wydaje wyrok» (Tt 3,10-11)"78.

${ }^{73}$ Oecumenius, Joannis Apostoli posterior catholica Epistola, art. cyt., k. 693.

74 Hilarius Arelatensis, Tractatus in septem Epistolas catholicas, art. cyt., k. 126.

75 Didymus Alexandrinus, In Epistolam divi Joannis sedundam enarratio, dz. cyt., k. 1810.

76 Beda Venerabilis, In III Epistolam Joannis, art. cyt., k. 124.

77 Beda Venerabilis, In II Epistolam Joannis, art. cyt., k. 120-122.

${ }^{78}$ Beda Venerabilis, In II Epistolam Joannis, art. cyt., k. 122. 
Nie dziwi zatem, że Klemens Aleksandryjski wyjaśnia, iż zdecydowane odcięcie się od takich ludzi i nałożona na nich ekskomunika jest czymś właściwym i nie stanowi środka zbyt radykalnego. W swoim komentarzu pisze zatem: ,[Jan] zabrania nam tych ludzi pozdrawiać i udzielać im gościny, co w okolicznościach, o których tu mowa, nie zdradza prawdziwej doktryny. Mówi też, aby nie dyskutować z osobami, które nie są zdolne rozumnie rozmawiać o sprawach Bożych, abyśmy przez takie argumenty, które są tylko pozorem prawdy, nie zostali odwiedzeni od prawdziwej nauki”. Biskup ten uważa, że nawet „nie należy modlić się z takimi ludźmi, ponieważ modlitwę zanoszoną w domu zwykle kończy się pozdrowieniem oraz życzeniami radości i pokoju", a to nie jest właściwe w przypadku heretyków ${ }^{79}$. Także Dydym Ślepy, komentując 3 J 11 i nawiązując do przeciwieństwa Chrystusa i Beliara (por. 2 Kor 6,15), uzasadnia konieczność oddzielania się od człowieka, który odrzuca Ewangelię: „Nie ma nic wspólnego światło z ciemnością, nie ma też wspólnoty Chrystusa z Beliarem. Kto zatem dobrze postępuje przez kontemplację i działanie i ma Chrystusa, który jest światłem, ten będzie się trzymał z daleka od ciemności i Beliara. Kto postępuje przewrotnie, ten działa z mocy Beliara i ciemności i nie widział Boga ani o Nim żadnej wiedzy nie ma"80.

Również Ekumeniusz przytacza te same słowa zaczerpnięte z Drugiego Listu do Koryntian i wypowiada się o łączeniu się chrześcijanina z ciemnością lub z Beliarem: „Ten, kto został oświecony poznaniem Chrystusa, nie ma takiej potrzeby, aby mieszać się z ciemnością przez naśladowanie bezbożnych z ich lubieżnymi uczynkami”. I dalej egzegeta tłumaczy, że człowiek czyniący dobro „z Boga jest”, a poznanie Boga oświeca jego oczy, dlatego też widzi Boga, który jest światłem świata, i w ten sposób „ma słowo życia”. Natomiast ten, kto czyni zło, Boga nie widzi, pozostając w ciemności; nie widzi w Bożym świetle także innych ludzi i dlatego wszystkich nienawidzi ${ }^{81}$.

Kończąc ten temat, można przytoczyć opinię Bedy Czcigodnego, który konstatuje, że heretycy „w rzeczywistości nie mniej siebie samych niż drogę prawdy zwalczają"82. Również i ten egzegeta znajduje w $2 \mathrm{~J}$ wezwanie do zdecydowanego odcięcia się od takich ludzi. Zapytuje retorycznie: „Kogo powinniśmy pozdrawiać, jeśli nie podobnego nam w obyczajach i w wierze?”. I zaleca: „Jeżeli przyjdzie do was ktoś, kto nie wyznaje wiary tak jak wy, nie tylko niech nie znajdzie u was żadnej opieki, ale nawet niech będzie uznany za niegodnego obietnicy”. W uzasadnieniu dowodzi, że obietnica zbawienia nie jest ofiarowana jednakowo wiernym i bezbożnym. Dlatego jeżeli wierni ofiarują ją również bezbożnym, zrównują siebie z nimi, a przez to ściągają na siebie należną im zagładę ${ }^{83}$.

${ }^{79}$ Clemens Alexandrinus, Adumbrationes in Epistolam II Joannis, art. cyt., k. 739-740.

80 Didymus Alexandrinus, In tertiam divi Joannis Epistolam enarratio, Patrologiae Cursus

Completus. Series Graeca 39, accurate J.P. Migne, Parisiis 1863, k. 1811.

81 Oecumenius, Joannis Apostoli tertia catholica Epistola, art. cyt., k. 701.

82 Beda Venerabilis, In II Epistolam Joannis, art. cyt., k. 121.

83 Oecumenius, Joannis Apostoli posterior catholica Epistola, art. cyt., k. 696. 
Ostatnim komentowanym przez ojców Kościoła tematem obecnym w 2 J i 3 J jest gościnność. Chwaleni są za nią Gajus i Demetriusz, jak to już zostało wspomniane wcześniej, egzegeci zaś piszą również o tej cnocie w ogólności. Komentując słowa Jana o udzielaniu gościny braciom, Ekumeniusz wywodzi, że Apostoł poucza nas, ,abyśmy nie czekali, aż potrzebujący przyjdą do nas, ale pospieszali i szukali ich, oferując pomoc". Przytacza też przykład takiej pomocy, jaki można znaleźć u Abrahama i Lota ${ }^{84}$. Chrześcijanie powinni naśladować te przykłady, zwłaszcza w stosunku do swych braci w wierze, ponieważ jak tłumaczy Beda Czcigodny: „z podwójnej przyczyny mogli oni wyruszyć dla imienia Pana: albo dla przepowiadania Jego imienia z własnej woli przybyli, albo z powodu wiary i wyznawania imienia świętego przez obywateli lub rodaków ze swojej ojczyzny zostali wygnani”. Ten sam mnich zauważa, że gościnność przejawia się nie tylko w darach materialnych, ale i w duchowych, a Jan ,nazywa współpracownikami prawdy także tych, którzy mając duchowe dary, udzielają innym wsparcia”. Według Bedy Jan, wzywając do pomocy biednym i pielgrzymom, „powołuje się na Pawła, który przywołuje słowa Chrystusa: «więcej szczęścia jest w dawaniu aniżeli w braniu» (Dz 20,35)". Już bezpośrednio słowa Chrystusa przytacza Beda, kiedy tłumaczy, że do tych, „którzy mają dary ducha [...] i z bogactwa cnót biednym świętym pomagają”, odnosi się zapowiedź: „Kto przyjmuje proroka jako proroka, nagrodę proroka otrzyma. Kto przyjmuje sprawiedliwego jako sprawiedliwego, nagrodę sprawiedliwego otrzyma" (Mt 10,41) ${ }^{85}$. Jeszcze dalej idzie w swym komentarzu Ekumeniusz, który łączy gościnność wobec głosicieli Ewangelii z otwartością na przyjęcie samego Boga: „Kto przyjmuje apostołów, przyjmuje ich nauczanie, przyjmując przez nich nauczającego Syna i Ojca. Przyjmując ich, staje się świątynią Boga" ${ }^{86}$.

Drugi i Trzeci List św. Jana to krótkie i proste pisma, które pozornie nie dają wielu możliwości wykazania się komentującym je egzegetom. Stąd zapewne niewielkie grono komentatorów, którzy poświęcili im swoją uwagę. Badając jednak pisma tych, którzy podjęli się tego zadania, można stwierdzić wcale niemałą liczbę tematów i myśli, jakie formułowali, wychodząc od tekstu tych listów. Można stwierdzić, że niejednokrotnie tekst biblijny służył za punkt wyjścia do zajęcia się tematem teologicznym, który wzbudzał zainteresowanie w czasie działalności komentatora, który znalazł uzasadnienie tegoż tematu właśnie w tekście $2 \mathrm{~J}$ lub $3 \mathrm{~J}$. Zachęca to do dalszego badania starożytnych komentarzy nie tylko do Ewangelii lub do wielkich listów Pawłowych, lecz również do najkrótszych i pozornie niepozornych ksiąg biblijnych.

${ }^{84}$ Oecumenius, Joannis Apostoli tertia catholica Epistola, art. cyt., k. 701.

85 Beda Venerabilis, In III Epistolam Joannis, art. cyt., k. 123.

${ }^{86}$ Oecumenius, Joannis Apostoli posterior catholica Epistola, art. cyt., k. 696. 


\section{Bibliografia}

\section{Źródla}

Novum Testamentum Graece, Hrsg. E. Nestle, B. Aland, 27. rev. Aufl., Stuttgart 1993.

Pismo Święte Starego i Nowego Testamentu w przekładzie z języków oryginalnych. Biblia Tysiąclecia, wyd. 5, Poznań 2000.

Beda Venerabilis, In II Epistolam Joannis, Patrologiae Cursus Completus. Series Latina 93, accurate J.P. Migne, Parisiis 1862, k. 119-122.

Beda Venerabilis, In III Epistolam Joannis, Patrologiae Cursus Completus. Series Latina 93, accurate J.P. Migne, Parisiis 1862, k. 121-124.

Didymus Alexandrinus, In Epistolam divi Joannis secundam enarratio, Patrologiae Cursus Completus. Series Graeca 39, accurate J.P. Migne, Parisiis 1863, k. 1809-1810.

Didymus Alexandrinus, In tertiam divi Joannis Epistolam enarratio, Patrologiae Cursus Completus. Series Graeca 39, accurate J.P. Migne, Parisiis 1863, k. 18111812.

Oecumenius, Joannis Apostoli posterior catholica Epistola, Patrologiae Cursus Completus. Series Graeca 119, accurate J.P. Migne, Parisiis 1881, k. 683-697.

Oecumenius, Joannis Apostoli tertia catholica Epistola, Patrologiae Cursus Completus. Series Graeca 119, accurate J.P. Migne, Parisiis 1881, k. 697-706.

Hilarius Arelatensis, Tractatus in septem Epistolas catholicas, Patrologiae Cursus Completus. Series Latina Supplementum 3 (ad vol. 49-66), accurate J.P. Migne, Parisiis 1963, k. 126-128.

Clemens Alexandrinus, Adumbrationes in Epistolam II Joannis, Patrologiae Cursus Completus. Series Graeca 9, accurate J.P. Migne, Parisiis 1857, k. 737-740.

\section{Opracowania}

Bednarz M., Pisma św. Jana, Academica 18, Tarnów 2004.

Campbell B.L., Honor, Hospitality and Haughtiness: The Contention for Leadership in 3 John, „Evangelical Quarterly” 77 (2005), no. 4, s. 321-341.

Czerski J., Ewangelia i Listy św. Jana. Wprowadzenie literackie, historyczne i teologiczne, Opolska Biblioteka Teologiczna 156, Opole 2016.

Drączkowski F., Dydym Ślepy, w: Encyklopedia katolicka, t. 4, red. R. Łukaszyk, L. Bieńkowski, F. Gryglewicz, Lublin 1983, k. 414-415.

Drączkowski F., Ekumeniusz, w: Encyklopedia katolicka, t. 4, red. R. Łukaszyk, L. Bieńkowski, F. Gryglewicz, Lublin 1983, k. 852-853.

Drączkowski F., Klemens Aleksandryjski, w: Encyklopedia katolicka, t. 9, red. A. Szostek, Lublin 2002, k. 98-102.

Encyklopedia biblijna, red. P.J. Achtemeier, Warszawa 1999. 
Gądecki S., Wstęp do pism Janowych, Gniezno 1991.

Gładyszewski L., Hilary z Arles, w: Encyklopedia katolicka, t. 6, red. J. Walkusz i in., Lublin 1993, k. 868.

Grégoire R., Beda il Venerabile, w: Dizionario patristico e di antichità cristiane, diretto da A. di Bernardino, vol. 1, Roma 1983, k. 515-518.

Griffith T., The Translation of О ПРОАГ QN in 2 John 9, „Tyndale Bulletin” 67 (2016), no. 1, s. 137-144.

Gryglewicz F., Listy katolickie. Wstęp, przekład z oryginatu, komentarz, Pismo Święte Nowego Testamentu 11, Poznań 1959.

Jensen M.D., Jesus „,Coming” in the Flesh: 2 John 7 and Verbal Aspect, „Novum Testamentum" 56 (2014), fasc. 3, s. 310-322.

Jończyk W., Relacyjne aspekty teologii Ewangelii i Listów św. Jana, „Studia Bobolanum" 1 (2017), s. 177-193.

Keener C.S., Komentarz historyczno-kulturowy do Nowego Testamentu, Prymasowska Seria Biblijna, Warszawa 2000.

Kruse C.G., The Letters of John, Pillar New Testament Commentary, Grand Rapids 2000.

Labate A., Ecumenio, w: Dizionario patristico e di antichità cristiane, diretto da A. di Bernardino, vol. 1, Roma 1983, k. 1063-1064.

Landrus H.L., Hearing 3 John 2 in the Voices of History, „Journal of Pentecostal Theology" 11 (2002), no. 1, s. 70-88.

List św. Jakuba, I-II List św. Piotra, I-III List św. Jana, List św. Judy, red. G. Bray, Ojcowie Kościoła komentują Biblię 11, Ząbki 2014.

Lorencin I., Hospitality versus Patronage: An Investigation of Social Dynamics in the Third Epistle of John, „Andrews University Seminary Studies” 46 (2008), no. 2, s. 165-174.

Marshall I.H., The Epistles of John, The New International Commentary on the New Testament, Grand Rapids 1978.

Mees R., Clemente di Alessandria, w: Dizionario patristico e di antichità cristiane, diretto da A. di Bernardino, vol. 1, Roma 1983, k. 706-711.

Mędala S., Trwanie w prawdzie (Drugi List św. Jana), w: Ewangelia św. Jana. Listy powszechne. Apokalipsa, red. J. Frankowski, oprac. R. Bartnicki i in., Wprowadzenie w myśl i wezwanie ksiąg biblijnych 10, Warszawa 1992, s. 90-96.

Mędala, S., Gościnność chrześcijańska (Trzeci List św. Jana), w: Ewangelia św. Jana. Listy powszechne. Apokalipsa, red. J. Frankowski, oprac. R. Bartnicki i in., Wprowadzenie w myśl i wezwanie ksiąg biblijnych 10, Warszawa 1992, s. 97-101.

Nautin P., Didimo il Cieco, w: Dizionario patristico e di antichità cristiane, diretto da A. di Bernardino, vol. 1, Roma 1983, k. 950-952.

Pricoco S., Ilario di Arles, w: Dizionario patristico e di antichità cristiane, diretto da A. di Bernardino, vol. 1, Roma 1983, k. 1747-1748. 
Rienecker F., Maier G., Leksykon biblijny, tłum. D. Irmińska, Prymasowska Seria Biblijna, Warszawa 2001.

Sikora A.R., ,Widzenie” Boga w Listach św. Jana, „Verbum Vitae” 16 (2009), s. $183-198$.

Skibiński T., Listy katolickie w starożytności chrześcijańskiej, „Vox Patrum” 28 (2008), s. 937-950.

Smalley S.S., 1, 2 and 3 John, World Biblical Commentary, Grand Rapids 2008.

Starowieyski M., Beda Czcigodny, w: Encyklopedia katolicka, t. 2, red. F. Gryglewicz, R. Łukaszyk, Z. Sułowski, Lublin 1976, k. 169-172.

\section{Streszczenie}

Celem niniejszej pracy jest prezentacja oraz omówienie treści starożytnych komentarzy do Drugiego i Trzeciego Listu św. Jana. Te dwa krótkie listy należą do najrzadziej czytanych i komentowanych ksiąg Nowego Testamentu. To samo, choć może nawet $\mathrm{w}$ jeszcze większym stopniu można powiedzieć o nielicznych starożytnych komentarzach do tych listów. Czytając dzieła Klemensa Aleksandryjskiego, Dydyma Ślepego, Bedy Czcigodnego, Ekumeniusza czy też Hilarego z Arles, można zauważyć, że komentując Drugi i Trzeci List Janowy koncentrowali się oni przede wszystkim na okolicznościach ich powstania i dociekali, kto dokładnie jest ich adresatem oraz co można ustalić na temat tożsamości wymienionych w nich osób. W ich komentarzach nie brakuje jednak również tematów teologicznych. Wychodząc od czasem pozornie nie związanych w teologią fragmentów listów, poruszali tematy teologiczne właściwe bardziej ich czasom niż czasom apostolskim. Wśród takich tematów można wymienić paruzję Chrystusa, realność Jego wcielenia lub relację Syna Bożego i Boga Ojca. W kręgu zainteresowania egzegetów pozostaje również konieczność zachowywania prawdziwej wiary oraz odcięcia się od heretyków, którzy ją zniekształcają.

Słowa kluczowe: Drugi List św. Jana, Trzeci List św. Jana, Klemens Aleksandryjski, Dydym

\section{The Second and Third Epistles of Saint John in the Commentaries of the Church Fathers}

\section{Summary}

The purpose of this paper is to present the content of the ancient commentaries on the Second and Third Epistles of Saint John the Apostle. These two short letters are some of the least read and commented on in the New Testament. The same, though perhaps even more so, can be said of the few ancient commentaries of these letters. Reading the works of Clement of Alexandria, Didymus the Blind, Bede the Venerable, Oecumenius or Hilary of Arles we notice that when commenting the Second 
and the Third Epistles of John they focused primarily on the circumstances of their creation and enquire as to the identity to whom the Epistles were addressed, and the identity of the other people mentioned in the text. However, their comments also include theological themes. Sometimes starting from seemingly unrelated theological passages in the Epistles, they dealt with theological themes more appropriate to their own time rather than to the apostolic time. Among such topics we can mention the parousia of Christ, the reality of His incarnation and the relationship of the Son of God with God the Father. Within this circle also remains the exegetes' interest in the necessity of preserving the true faith and of dissociating themselves from heretics who distort it.

Key words: Second Epistle of John, Third Epistle of John, Clement of Alexandria, Didymus the Blind, Bede the Venerable, Oecumenius Ślepy, Beda Czcigodny, Ekumeniusz 